\title{
Miłosierdzie jako synonim zbawienia w Koranie. Refleksje lingwistyczno-teologiczne
}

Dla badań teologicznych z zakresu historii religii bardzo ważna jest świadomość „nieokreśloności przestrzeni”. Pozwala ona na kierowanie energii i czasu na „wypełnianie luk", czyli badanie tego, co opracowano dotychczas w sposób niedostateczny lub czego jeszcze nie opracowano ${ }^{1}$. Takim właśnie zagadnieniem jest idea zbawienia w Koranie, która z racji tego, że w tekście tej księgi nie występuje pojęcie „zbawienia”, została potraktowana przez specjalistów jako nieobecna. Tymczasem jest ona mocno zakorzeniona w tekście koranicznym, dobrze udokumentowana i wyrażona wieloma derywatami utworzonymi od licznej grupy rdzeni języka arabskiego.

Tematyka miłosierdzia jest obecnie reprezentowana w licznych pracach teologicznych z zakresu teologii chrześcijańskiej. Stanowi najczęściej refleksję nad objawieniem św. Siostry Faustyny i nauczaniem bł. Jana Pawła II. W optyce zagadnień dotyczących miłosierdzia Bożego odnajdują się liczne dziedziny teologiczne², łącznie z tymi, które wykraczają poza zakres teologii katolickiej. Mam tu na myśli koncepcje miłosierdzia $\mathrm{w}$ teologii dwóch religii monoteistycznych, judaizmu ${ }^{3}$ islamu$u^{4}$. Ten

${ }^{1}$ Por. K. Kleszczowa, Językoznawstwo historyczne w świetle współczesnej historiografii, [w:] tejże, Tajemnice dynamiki języka. Księga jubileuszowa, Katowice 2012, s. 45.

${ }^{2}$ Przykładem może być praca zbiorowa Dogmatyka w perspektywie Bożego miłosierdzia, red. K. Góźdź, K. Guzowski, Lublin 2010.

${ }^{3}$ Por. S. Hałas, Biblijne stownictwo miłości i miłosierdzia na zderzeniu kultur. Określenia hebrajskie i ich greckie odpowiedniki, Kraków 2011.

${ }^{4}$ Por. B. Abdallah, Konceptualizacja wartości w Koranie na przykładzie analizy pojęcia miłosierdzia, [w:] Arabowie - islam - świat, red. M. M. Dziekan, I. Kończak, Łódź 2007, s. 157-167; A. Mrożek, B. Prochwicz-Studnicka, M. Teperska-Klasińska, Pomiędzy rajem a piekłem. Tradycja judeochrześcijańska a Koran, [w:] Przez kultury i cywilizacje. Pamięci Profesora Andrzeja Flisa, red. A. Kowalska, A. Mrożek, A. Świerzowska, M. Teperska-Klasińska, Kraków 2011, s. 183-203. Na wstępie artykuły autorzy zaznaczają: „W polskiej literaturze arabistycznej i islamistycznej problematyka eschatologiczna do dziś pozostaje na marginesie głównych zainteresowań badawczych. Nie doczekała się dogłębnych opracowań, a zatem pewne kwestie zostały przedstawione pobieżnie i w sposób nieco uproszczony". Jest to opinia w pewnym sensie nieścisła, ponieważ właśnie autor niniejszego artykułu zajmuje się 
skromny artykuł dotyczy jednego z synonimów idei zbawienia w Koranie. Jest nim właśnie miłosierdzie Boże 5 .

W Koranie pojawia się idea Boga miłosierdzia. Wyrażają ją derywaty oparte na rdzeniu رrhm. Mimo pewnych podobieństw do biblijnej nauki o miłosierdziu Boga, autor Koranu idzie własną drogą, tworząc własną koncepcję na ten temat. Charakterystyczną cechą mówienia o miłosierdziu Bożym w Koranie jest stosowanie przez autora tekstu formuł rytualnych, zawierających określenia dotyczące Bożego miłosierdzia. Uzupełniające do tej zasady są treści wyrażane są derywatami utworzonymi na bazie rdzenia ر رأف r'f. Zawierają one motyw dobrotliwości Boga.

\section{Tło językowe - wyrażenia oparte na rdzeniu رحم rḥm}

Termin ألرَّحْنُن ’ar-Rahmānn $n^{u}$, „Miłosierny” jest w Koranie najbardziej charakterystycznym odniesieniem do Boga (S. XIX, 61. 85. 87. 96; XX, 109; XXXVI, 11. 23; LXVIII, 29). Jest to przymiot najczęściej przypisywany Bogu'. W języku południowoarabskim Raḥmanān było nazwą Boga chrześcijańskiego (V wiek). Zachowało się wiele starożytnych chrześcijańskich inskrypcji południowoarabskich, w których zawarte jest to określenie Boga. Wyrażenie to pochodzi z języka aramej-

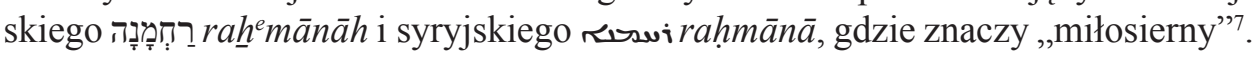

رَجَْ Jest ono oparte na rdzeniu رحمَ $\mathrm{rhm}$. W temacie podstawowym czasownik rahima znaczy „litować się, współczuć, okazywać litość, przebaczać”. W II temacie

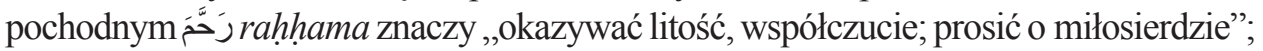

badaniem zagadnień dotyczących eschatologii Koranu i jest autorem pierwszej w Polsce monografii na ten temat (por. przyp. następny), która niestety, „dziwnym zrządzeniem losu”, nie może jakoś ukazać się w druku. Przedłożony artykuł ma zapełnić tylko częściowo tę „lukę”.

${ }^{5}$ Artykuł ten jest rozwiniętym i poprawionym fragmentem jednego z rozdziałów rozprawy doktorskiej pt. Idea zbawienia w Koranie. Studium lingwistyczno-teologiczne napisanej na seminarium naukowym $\mathrm{z}$ teologii fundamentalnej pod kierunkiem ks. prof. dr. hab. Łukasza Kamykowskiego, obronionej 19 stycznia 2010 roku na Wydziale Teologicznym Uniwersytetu Jana Pawła II w Krakowie. Jej recenzentami byli: p. prof. dr hab. Janusz Danecki (arabista; Uniwersytet Warszawski; Szkoła Wyższa Psychologii Społecznej w Warszawie) oraz ks. dr hab. Stanisław Hałas SCJ, prof. UPJPII (biblista; Uniwersytet Papieski Jana Pawła II w Krakowie). Praca została uznana za najlepszą na Wydziale Teologicznym w roku akademickim 2010/2011 i 22 października jej autor otrzymał nagrodę JM Rektora UPJPII.

${ }^{6}$ Por. J. Nosowski, Teologia Koranu. Wykład systematyczny, Warszawa 1970, s. 91.

${ }^{7}$ Por. C. Brockelmann, Syrische Grammatik mit Paradigmen, Literatur, Chrestomatie und Glossar, Leipzig 1976, s. 724a; Brünnow-Fischer, Arabische Chrestomathie aus Prosaschriftstellern, Leipzig 1974, s. 48; M. Gaudefroy-Demombynes, Narodziny islamu, tłum. H. Olędzka, Warszawa 1988, s. 199; K. Kościelniak, XX wieków chrześcijaństwa w kulturze arabskiej, t. 1: Arabia starożytna. Chrześcijaństwo w Arabii do Mahometa († 632), Kraków 2000, s. 119-120; D. Madeyska, Historia świata arabskiego. Okres klasyczny od starożytności do końca epoki Umajjadów (750), Warszawa 1999, s. 70; S. Segert, Altaramäische Grammatik, Leipzig 1975, s. 551; W. P. Turek, Wyrazy obcego pochodzenia w Koranie jako świadectwo arabskich kontaktów językowych i kulturowych z otaczającym światem, [w:] Wręgu cywilizacji Pólksiężyca. 6. Ogólnopolska Konferencja Arabistyczna. Kraków 14-15 maja 2002. Materiaty, red. B. Michalak-Pikulska, Kraków 2002, s. 243. 
w V temacie pochodnym ترَحََّ taraḥhama - „litować się nad kimś, modlić się

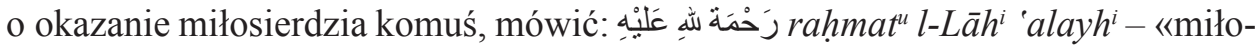
sierdzie Boga nad nim»”; w VI temacie pochodnym ترَاحَ tarāhama - „okazywać nawzajem miłosierdzie”; w X temacie إِنْترْْ wzywać miłosierdzia". Rzeczownikiem odczasownikowym utworzonym na bazie tego rdzenia jest رَحَحَ rahmat ${ }^{u n}$ - „,miłosierdzie, litość”, a przymiotnikami forma

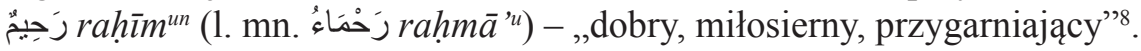

\section{Basmala - formuła podstawowa (znaczenie i geneza)}

Przymiotnik ten w połączeniu z wyżej wymienionym wyrażeniem występuje

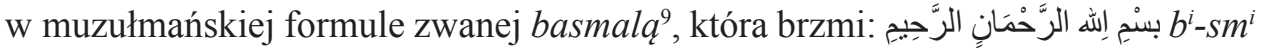
l-Lāhi ${ }^{i}$-Raḥmān ${ }^{i}$ r-rahím ${ }^{i}$ - „W imię Boga Miłosiernego, Litościwego”. Formuła ta jest wyrazem formalnej przynależności do wspólnoty wyznawców islamu. Od niej zaczynają się wszystkie sury z wyjątkiem IX. Od niej każdy muzułmanin powinien rozpoczynać wszystkie swoje czynności. Teksty pisane przez świątobliwych muzułmanów w rodzaju listów, rozpraw naukowych, książek zaczynają się od tej formuły. Stanowi ona jeden z najbardziej popularnych napisów w ornamentyce muzułmańskiej na budynkach i w kaligrafii w rękopisach ${ }^{10}$.

${ }^{8}$ Por. A. A. Ambros, S. Procházka, A Concise Dictionary of Koranic Arabic, Wiesbaden 2004, s. 110; R. Baalbaki, AL-MAWRID. A Modern Arabic-English Dictionary, Beirut 1993, s. 580; X. К. Баранов, Арабско-русский словарь, Москва 1989, s. 291; J. Danecki, J. Kozłowska, Słownik arabsko-polski, Warszawa 1996, s. 370; F. Dieterici, Arabisch-deutsches Handwörterbuch zum Koran und Thier und Mensach vor dem König der Genien..., Vaduz/Lichtenstein 1994 (Unveränderter Neudruck der Ausgabe von 1881), s. 61; J. Łacina, Stownik arabsko-polski, Poznań 1997, s. 443; A. A. Nadwi, Vocabulary

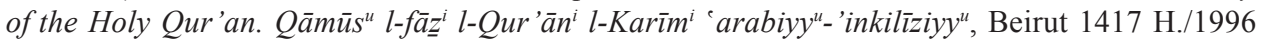

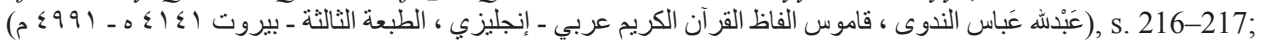
'A. M. 'OMAR, Dictionary Of The Holy Qur'ân. Arabic Words - English Meanings (With Notes) (Classical Arabic Dictionaries Combined), Hockessin (USA)/Rheinfelden (Germany) 2005, s. 205207; J. Penrice, A Dictionary of the Qur'ān with Copious Grammatical References and Explanations of the Text, London 1873 (New Revised Edition 1988), s. 56; H. Wehr, Arabisches Wörterbuch für die Schriftsprache der Gegenwart, Leipzig 1958, s. 299.

9 Arab. بَ بَسَّْلة basmalat ${ }^{u n}$-,wypowiadnie formuły zwanej basmalą" i czasownik بَ basmala w znaczeniu - „mówić: «w imię Boga ...»”. Rzeczownik ten oraz czasownik należą do specyficznej grupy rdzeni czterospółgłoskowych, które powstały ze skrócenia całej frazy zwanej basmalą. Jest kilka

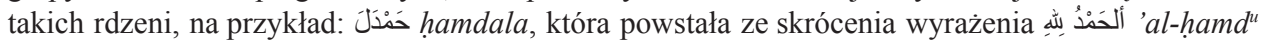
$l^{i}-l-L \bar{a} h^{i}$ - „,chwała niech będzie Bogu”. Por. R. Baalbaki, AL-MAWRID. A Modern Arabic-English Dictionary, s. 237; Х. К. Баранов, Арабско-русский словарь, s. 71; J. Danecki, Gramatyka..., s. 108; J. Danecki, J. Kozłowska, Słownik arabsko-polski, s. 138; J. Łacina, Słownik arabsko-polski, s. 147; H. Wehr, Arabisches Wörterbuch..., s. 51.

${ }^{10}$ Por. J. Danecki, Kultura islamu. Stownik, Warszawa 1997, s. 48; Arabowie. Słownik encyklopedyczny, red. M. M. Dziekan, Warszawa 2001, s. 105; Tegoż, Symbolika arabsko-muzulmańska. Mały słownik, Warszawa 1997, s. 20; Y. H. Safadi, Islamic Calligraphy, Londyn 1978, s. 32-39. 
W tekstach biblijnych nie ma zbyt wielu par desygnatów, z których jeden dotyczy miłosierdzia Bożego. Tekstem, w którym pary koraniczne z tym wyrażeniem wykazują największe podobieństwo jest Pwt 13, 18. Oba wyrazy użytego tu wyra-

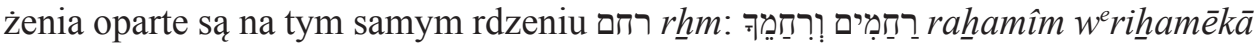
- „litość i miłosierdzie” (arab. że u podstaw koncepcji miłosiernego Boga i Jego miłosierdzia w Koranie leży imię Boga chrześcijańskiego, zapożyczone z kręgu języka południowoarabskiego. Wyżej wspomniany wers stanowi rodzaj wzorca, w oparciu o który twórca islamu formułował swoje myśli na temat Bożego miłosierdzia. Całość jednak tej koncepcji wynika z własnej refleksji autora Koranu nad tą tajemnicą wiary.

\section{Kontekstowe użycie formuły doksologicznej (typologia)}

Drugą formułą zawierającą określenie Boga miłosiernego jest zwrot: إنَّ أله غَفورُ رَحِيُم 'inn ${ }^{a}$ l-Lā $h^{u} \dot{g} a f u \bar{u} r^{u n}$ rahīm ${ }^{u n}$ - „Zaprawdę, Bóg jest przebaczający, miłosierny!”. Używana jest najczęściej jako rodzaj teologicznej syntezy treści objawionych w wersetach ją poprzedzających, dla nadania im rangi autorytetu Bożego słowa. Formuła ta występuje w różnych odmianach kontekstowych. Sporządzona niżej tabela pozwala na ukazanie tej różnorodności:

\section{Zَفور + رَحِيمٌ مdanie imienne (nominalne) z orzecznikiem typu}

\begin{tabular}{|c|c|c|c|}
\hline $\begin{array}{l}\text { Typ i podtyp } \\
\text { zdania }\end{array}$ & Lokalizacja & Tekst formuły & $\begin{array}{l}\text { Charakterystyka } \\
\text { składniowo-stylistyczna }\end{array}$ \\
\hline \multirow[t]{5}{*}{$\begin{array}{l}\text { podtyp Ia } \\
z \text { imieniem } \\
\text { wtaściwym Boga }\end{array}$} & $\begin{array}{l}\text { S. II, 218; III, 31. } \\
\text { 129; V, 74; VIII, 70; } \\
\text { IX, 27; XXIV, 22; } \\
\text { LVII, } 28\end{array}$ & 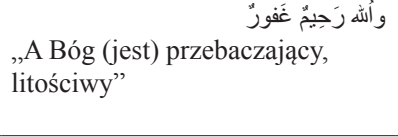 & $\begin{array}{l}\text { z poprzedzającym spójnikiem } \\
\text { kontynuacji } و w a-\end{array}$ \\
\hline & $\begin{array}{l}\text { S. V, 34. 39; IX, } \\
\text { 5. 99. 102; XLIX, } \\
\text { 14; LXXIII, } 28 \\
\end{array}$ & 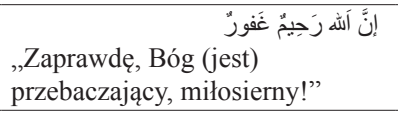 & $\begin{array}{l}\text { z poprzedzającą partykułą } \\
\text { emfazy إنَ' 'inn }{ }^{a}\end{array}$ \\
\hline & $\begin{array}{l}\text { S. III, 89; V, 3; } \\
\text { XXIV, 5; LVIII, 12; } \\
\text { LXIV, } 14\end{array}$ & 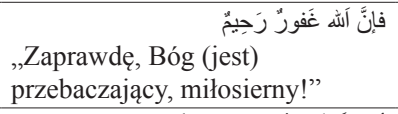 & 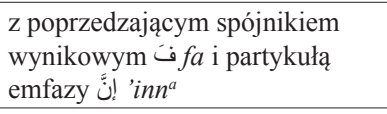 \\
\hline & S. XLII, 5 & 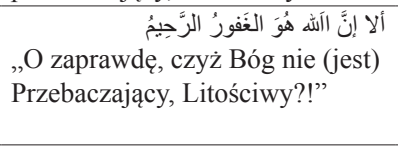 & $\begin{array}{l}\text { nominatiwus pendens z partykułą } \\
\text { لأ 'a-lā wprowadzającą pytanie } \\
\text { retoryczne i poprzedzającą } \\
\text { partykułą emfazy نُّ 'inn }{ }^{a}\end{array}$ \\
\hline & S. IV, 110 & 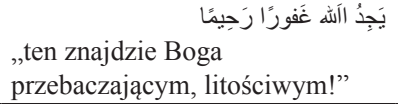 & jako fraza kontekstowa \\
\hline
\end{tabular}

${ }^{11}$ Por. Biblia Hebraica Stuttgartensia. תורה נביאים וכתובים, edid. K. Elliger, W. Rudolph, Editio quinta emendata opera A. Schenker, Stuttgart 1997, s. 311 (dalej: BH).

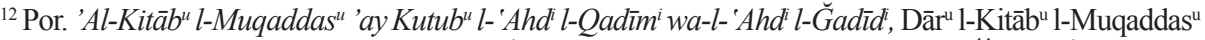

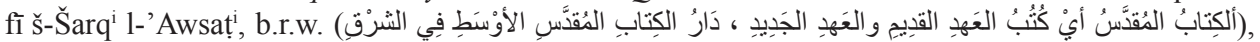
s. 653 (dalej: ABST). 


\begin{tabular}{|c|c|c|c|}
\hline $\begin{array}{l}\text { Typ i podtyp } \\
\text { zdania }\end{array}$ & Lokalizacja & Tekst formuły & $\begin{array}{l}\text { Charakterystyka } \\
\text { składniowo-stylistyczna }\end{array}$ \\
\hline \multirow{2}{*}{$\begin{array}{l}\text { podtyp Ib } \\
\text { z imieniem } \\
\text { zastepczym Boga } \\
\text { w 3. osobie liczby } \\
\text { pojedynczej }\end{array}$} & S. X, 107 & $\begin{array}{l}\text { وهُو الغَفورُ الرَّحِيُ } \\
\text { „On (jest) Przebaczający, } \\
\text { Litościwy!” }\end{array}$ & $\begin{array}{l}\text { z poprzedzającym spójnikiem } \\
\text { kontynuacji } و w a-\end{array}$ \\
\hline & $\begin{array}{l}\text { S. XII, 98; XXVIII, } \\
\text { 16; XXXIX, } 53\end{array}$ & $\begin{array}{l}\text { إنَّهُ هُوَ الغَفورُ الرَّحِيحم (jest) } \\
\text { Przebaczajacy, Litościwy!” }\end{array}$ & $\begin{array}{l}\text { z poprzedzajacą partykułą } \\
\text { emfazy نّ 'inn }{ }^{a} \text { i zaimkiem } \\
\text { sufiksalnym 3. osoby liczby } \\
\text { pojedynczej }\end{array}$ \\
\hline \multirow{2}{*}{$\begin{array}{l}\text { podtyp Ic } \\
\text { z imieniem } \\
\text { zastepczym Boga } \\
\text { w 1. osobie liczby } \\
\text { pojedynczej }\end{array}$} & S. XV, 49 & $\begin{array}{l}\text { أنّيّي أنا الغَفورُ الرَّحِيُُ } \\
\text { „Ja (jestem) Przebaczający, } \\
\text { Litościwy!” }\end{array}$ & $\begin{array}{l}\text { z poprzedzającym zaimkiem } \\
\text { أنْ 'an i zaimkiem sufiksalnym } \\
\text { 1. osoby liczby pojedynczej }\end{array}$ \\
\hline & S. XXVII, 11 & 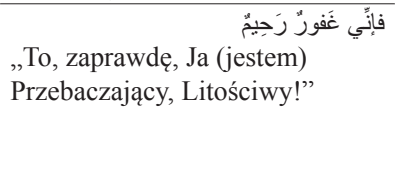 & $\begin{array}{l}\text { z poprzedzającym spójnikiem } \\
\text { wynikowym } \operatorname{efa} \text { i partykułą } \\
\text { emfazy إن 'inn }{ }^{a} \text { oraz zaimkiem } \\
\text { sufiksalnym } 1 . \text { osoby liczby } \\
\text { pojedynczej }\end{array}$ \\
\hline $\begin{array}{l}\text { podtyp Id } \\
\text { z imieniem } \\
\text { zastepczym Boga } \\
\text { w 1. osobie liczby } \\
\text { mnogiej }\end{array}$ & S. XLI, (31-) 32 & 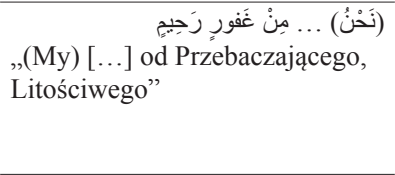 & $\begin{array}{l}\text { jako fraza kontekstowa w formie } \\
\text { wyrażenia przyimkowego } \\
\text { z przyimkiem من min }\end{array}$ \\
\hline $\begin{array}{l}\text { podtyp Ie } \\
\text { z imieniem Boga } \\
\text { رَبِ }\end{array}$ & $\begin{array}{l}\text { S. XVI, 110. 119; } \\
\text { VII, } 153\end{array}$ & $\begin{array}{l}\text { إنَّ رَبَّكَ مِنْ بَعْدَهَا لغفورْ رَحِيُّ } \\
\text { „Twój Pan (jest | będzie) } \\
\text { z pewnością przebaczający } \\
\text { i litościwy” }\end{array}$ & $\begin{array}{l}\text { z poprzedzającą partykułą } \\
\text { emfazy إنَّ 'inn }{ }^{a}\end{array}$ \\
\hline
\end{tabular}

\section{Zdفور + زَحِيْ}

\begin{tabular}{|c|c|c|c|}
\hline $\begin{array}{l}\text { Typ i podtyp } \\
\text { zdania }\end{array}$ & Lokalizacja & Tekst formuły & $\begin{array}{l}\text { Charakterystyka } \\
\text { składniowo-stylistyczna }\end{array}$ \\
\hline $\begin{array}{l}\text { podtyp II } \\
\text { z imieniem } \\
\text { właściwym Boga }\end{array}$ & $\begin{array}{l}\text { S. IV, 96. 100. 152; } \\
\text { XXV, 70; XLVIII, } \\
14\end{array}$ & 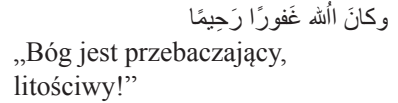 & $\begin{array}{l}\text { zdanie czasownikowe z كان } \\
\text { kāna poprzedzone spójnikiem } \\
\text { kontynuacji ǵwa- }\end{array}$ \\
\hline
\end{tabular}

\section{Zdanie imienne (nominalne) z orzecznikiem typu نوَّابُ + زَحِيمٌ}

\begin{tabular}{|c|c|c|c|}
\hline $\begin{array}{l}\text { Typ i podtyp } \\
\text { zdania }\end{array}$ & Lokalizacja & Tekst formuły & $\begin{array}{l}\text { Charakterystyka } \\
\text { składniowo-stylistyczna }\end{array}$ \\
\hline \multirow[t]{2}{*}{$\begin{array}{l}\text { podtyp IIIa } \\
\text { z imieniem } \\
\text { wtaściwym Boga }\end{array}$} & S. IX, 104 & 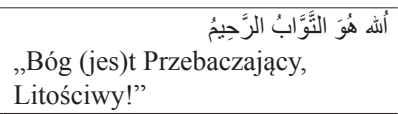 & nominatiwus pendent \\
\hline & S. IV, 64 & 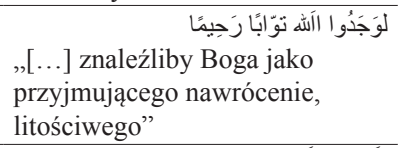 & jako fraza kontekstowa \\
\hline $\begin{array}{l}\text { podtyp IIIb } \\
\text { z imieniem } \\
\text { zastepczym Boga } \\
\text { w 3. osobie liczby } \\
\text { pojedynczej }\end{array}$ & S. II, 37.54 & 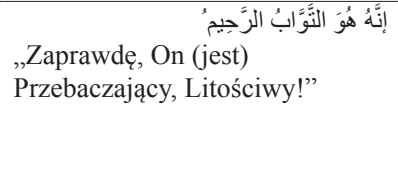 & $\begin{array}{l}\text { z poprzedzajaca partykułą } \\
\text { emfazy }{ }^{\prime} \operatorname{l}^{\prime} i n n^{a} \text { i zaimkiem } \\
\text { sufiksalnym 3. osoby liczby } \\
\text { pojedynczej }\end{array}$ \\
\hline
\end{tabular}




\begin{tabular}{|c|c|c|c|}
\hline $\begin{array}{l}\text { Typ i podtyp } \\
\text { zdania }\end{array}$ & Lokalizacja & Tekst formuły & $\begin{array}{l}\text { Charakterystyka } \\
\text { składniowo-stylistyczna }\end{array}$ \\
\hline $\begin{array}{l}\text { podtyp IIIc } \\
\text { z imieniem } \\
\text { zastepczym Boga } \\
\text { w 2. osobie liczby } \\
\text { pojedynczej }\end{array}$ & S. II, 128 & 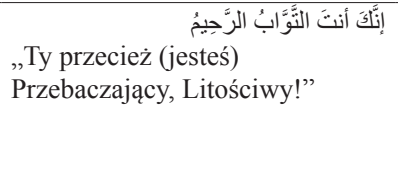 & $\begin{array}{l}\text { z poprzedzajaca partykułą } \\
\text { emfazy نُّ 'inn }{ }^{a} \text { i zaimkiem } \\
\text { sufiksalnym 2. osoby liczby } \\
\text { pojedynczej }\end{array}$ \\
\hline $\begin{array}{l}\text { podtyp IIId } \\
\text { z imieniem } \\
\text { zastępczym Boga } \\
\text { w 1. osobie liczby } \\
\text { pojedynczej }\end{array}$ & S. II, 160 & 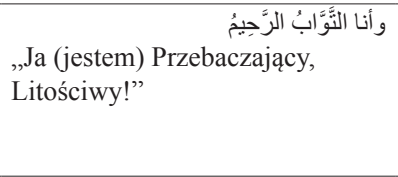 & $\begin{array}{l}\text { z poprzedzającym spójnikiem } \\
\text { kontynuacji g } w a-\end{array}$ \\
\hline
\end{tabular}

\section{Zdanie czasownikowe z orzecznikiem typu زوَابٌ + رَحِيمّ}

\begin{tabular}{|c|c|c|c|}
\hline $\begin{array}{l}\text { Typ i podtyp } \\
\text { zdania }\end{array}$ & Lokalizacja & Tekst formuły & $\begin{array}{l}\text { Charakterystyka } \\
\text { składniowo-stylistyczna }\end{array}$ \\
\hline $\begin{array}{l}\text { podtyp II } \\
z \text { imieniem } \\
\text { wtaściwym Boga }\end{array}$ & S. IV, 16 & 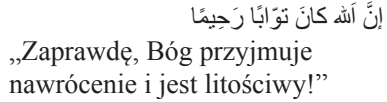 & $\begin{array}{l}\text { zdanie czasownikowe z كانَ kāna } \\
\text { poprzedzone partykułą emfazy } \\
\text { إنَّ 'inn }{ }^{a}\end{array}$ \\
\hline
\end{tabular}

\section{Zَؤْن + رَجِيمٌ}

\begin{tabular}{|c|c|c|c|}
\hline $\begin{array}{l}\text { Typ i podtyp } \\
\text { zdania }\end{array}$ & Lokalizacja & Tekst formuły & $\begin{array}{l}\text { Charakterystyka } \\
\text { składniowo-stylistyczna }\end{array}$ \\
\hline $\begin{array}{l}\text { podtyp IVa } \\
\text { z imieniem } \\
\text { właściwym Boga }\end{array}$ & $\begin{array}{l}\text { S. LVII, 9; } \\
(\mathrm{IX}, 128)^{*} \\
(\mathrm{II}, 143)^{* *}\end{array}$ & 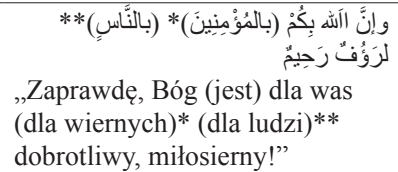 & $\begin{array}{l}\text { z poprzedzającym spójnikiem } \\
\text { kontynuacji و wa- i partykułą } \\
\text { emfazy نّا! 'inn }{ }^{a}\end{array}$ \\
\hline $\begin{array}{l}\text { podtyp IVb } \\
\text { z imieniem } \\
\text { zastepczym Boga } \\
\text { w 2. osobie liczby } \\
\text { pojedynczej }\end{array}$ & S. LIX, 10 & 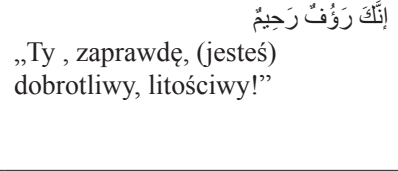 & $\begin{array}{l}\text { z poprzedzajaca partykułą } \\
\text { emfazy } \dot{u}^{\prime} \text { 'inn }{ }^{a} \text { i zaimkiem } \\
\text { sufiksalnym } 2 . \text { osoby liczby } \\
\text { pojedynczej }\end{array}$ \\
\hline
\end{tabular}

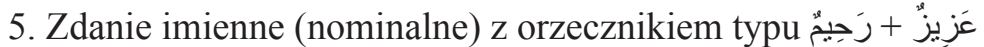

\begin{tabular}{|c|c|c|c|}
\hline $\begin{array}{l}\text { Typ i podtyp } \\
\text { zdania }\end{array}$ & Lokalizacja & Tekst formuły & $\begin{array}{l}\text { Charakterystyka } \\
\text { składniowo-stylistyczna }\end{array}$ \\
\hline \multirow{3}{*}{$\begin{array}{l}\text { podtyp Va } \\
\text { z imieniem } \\
\text { zastepczym Boga } \\
\text { w 3. osobie liczby } \\
\text { pojedynczej }\end{array}$} & S. XXX, 5 & وهُو العَزيزُ الرَّحِيُُ & $\begin{array}{l}\text { z poprzedzającym spójnikiem } \\
\text { kontynuacji g wa- }\end{array}$ \\
\hline & S. XLIV, 42 & $\begin{array}{l}\text { إنُهُ هُوَ العزَزيزُ الرُّحِيُُ } \\
\text { „Zaprawdę, On (jest) Potężny, } \\
\text { Litościwy!” }\end{array}$ & $\begin{array}{l}\text { z poprzedzającą partykułą } \\
\text { emfazy إن 'inn }{ }^{a} \text { i zaimkiem } \\
\text { sufiksalnym } 3 \text {. osoby liczby } \\
\text { pojedynczej }\end{array}$ \\
\hline & S. XXXVI, 5 & 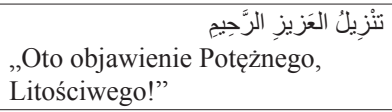 & $\begin{array}{l}\text { konstrukcja dopełniaczowa } \\
\text { (status constructus) jako fraza } \\
\text { kontekstowa }\end{array}$ \\
\hline
\end{tabular}




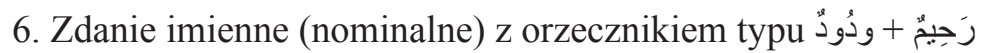

\begin{tabular}{|c|c|c|c|}
\hline $\begin{array}{l}\text { Typ i podtyp } \\
\text { zdania }\end{array}$ & Lokalizacja & Tekst formuły & $\begin{array}{l}\text { Charakterystyka } \\
\text { składniowo-stylistyczna }\end{array}$ \\
\hline & S. XI, 90 & 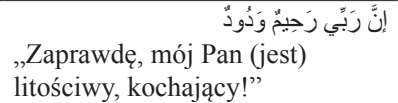 & $\begin{array}{l}\text { z poprzedzającą partykuła } \\
\text { emfazy إنَّ 'inn }{ }^{a}\end{array}$ \\
\hline
\end{tabular}

\section{Objawienie a miłosierdzie Boga}

Oprócz tych par desygnatów, które odnoszą się do przymiotów Boga, z których przynajmniej jednym jest określenie Boga jako miłosiernego, w Koranie użyte zostają także pary desygnatów, które stanowią rodzaj charakterystyki objawienia Bożego. Objawienie Boże otrzymane przez wiernych od Boga w Koranie jest nazywane (و) هُدَى ورَحْمَة (و wa-hudà wa-rahmat ${ }^{u n}$-,droga prosta i miłosierdzie” (S. VI, 157; VII, 52;

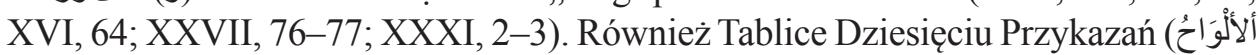
'al-'alwāh $h^{u}$ ) są nazywane tym wyrażeniem (S. VII, 154). Tora zaś jest nazywana

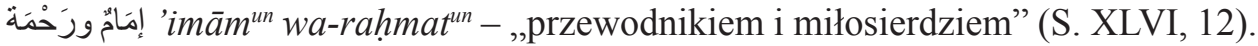

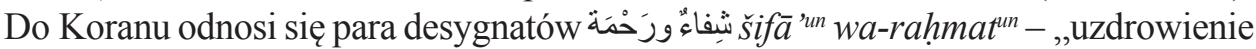
i miłosierdzie" (S. XVII, 82). Są też pary określeń dotyczące sytuacji wiernych zbawionych. Męczennicy są tymi, którzy dostępują مَغْفَرَة مِنَ للهِ ورَحْمَ magifirat ${ }^{u n}$ min $^{a}$ l-Lāhi wa-rahmat ${ }^{u n}$ - ,przebaczenia od Boga i miłosierdzia” (S. III, 157). Wiernych

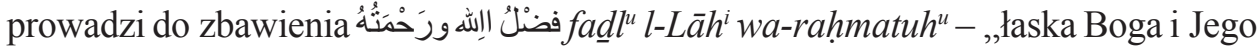

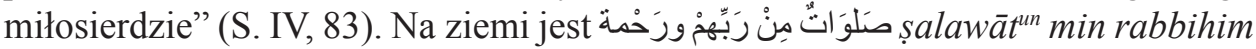
wa-rahmat ${ }^{\text {un }}$ - „błogosławieństwo od Pana i miłosierdzie” (S. II, 157). Dlatego prorok

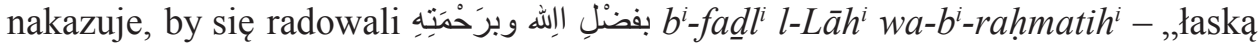
Boga i Jego miłosierdziem" (S. X, 58). Gdy wierzą i z ich wiary wynikają dobre

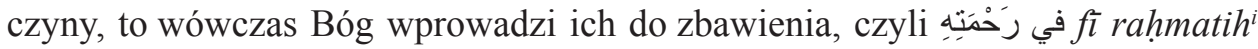

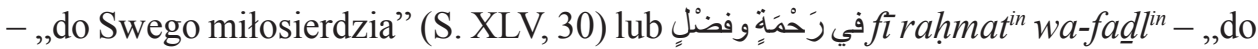
Swego miłosierdzia i do Swojej łaski” (S. IV, 175).

Określenie powołania skierowanego do ludzi przez twórcę islamu jako Dobrą Nowinę zostaje nazwane przy pomocy triady wyrażeń:

\begin{tabular}{|c|c|c|}
\hline \multicolumn{3}{|l|}{ S. IX, 21} \\
\hline „Ich Pan obwieści im radosną nowinę & yubašširuhum rabbuhum & 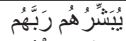 \\
\hline przez miłosierdzie od Niego & $b^{i}$-rahmat $\operatorname{minh}^{u}$ & بِرَحْمَةِة مِنْهُ \\
\hline i przez upodobanie & $w a-r i \underline{d} w a \bar{a} n^{i n}$ & ورِضٍِْوَانٍ \\
\hline i przez Ogrody" & $w a-\dot{g} a n n \bar{a} t^{i n}$ & ورجنَّاتٍ \\
\hline
\end{tabular}

Są też triady określeń, które odnoszą się do Księgi danej przez Boga Mojżeszowi.

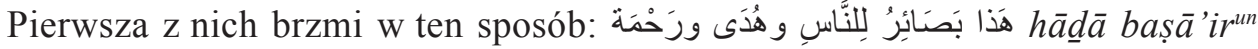
$l^{i}$-n-nās $s^{i}$ wa-hudà wa-rahmmat ${ }^{u n}$ - ,wskazówki dla ludzi i droga prosta i miłosierdzie" (S. XXXVIII, 43; XLV, 20). Autor Koranu rozszerza tę terminologię charakteryzującą

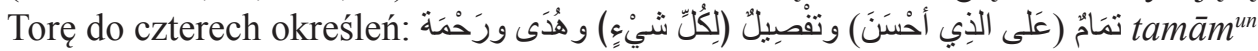




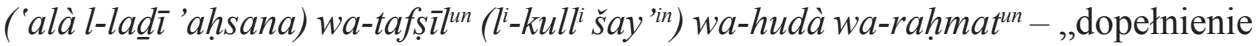
(dla czyniących dobro) i wyjaśnienie (dla każdej rzeczy) i droga prosta i miłosierdzie" (S. VI, 154). Podobnie ma się rzecz z określeniem roli opowiadań o patriarchach Starego Testamentu, o których wspomina w Koranie. Sens tych opowiadań jest

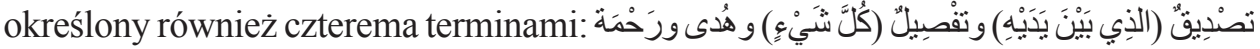

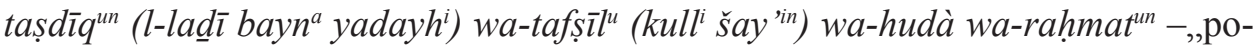
twierdzenie prawdziwości (tego, co było przed nim) i wyjaśnianie (wszystkich rzeczy), i droga prosta, i miłosierdzie" (S. XII, 111). Wreszcie otrzymane przez siebie objawienie autor Koranu charakteryzuje również czterema terminami:

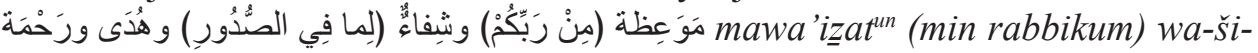
$f \bar{a}^{\text {un }}\left(l^{i}-m \bar{a} f i-s-s ̦ d \bar{u} r^{i}\right)$ wa-hudà wa-rahmat ${ }^{u n}$ - ,napomnienie (od waszego Pana) i uleczenie (tego, co jest w piersiach), i droga prosta, i miłosierdzie" (S. X, 57). Księga Koranu też otrzymuje taką, wyrażoną przez cztery określenia, charakte-

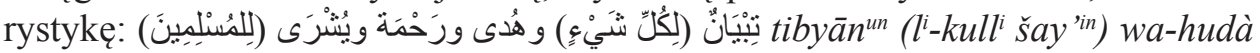
wa-raḥmat ${ }^{u n}$ wa-yušrà $\left(l^{i}-l\right.$-musliminn ${ }^{a}$ ) - ,wyjaśnienie (dla każdej rzeczy), i droga prosta, i miłosierdzie, i radosna wieść (dla całkowicie poddanych)" (S. XVI, 89).

\section{Miłosierdzie a zbawienie}

Bóg jest całkowicie suwerenny w obdarowywaniu zbawieniem. Wyrażają to następujące formuły:

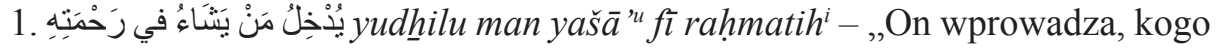
chce, do Swego miłosierdzia" (S. XLII, 8; XLVIII, 25; LXXVI, 31);

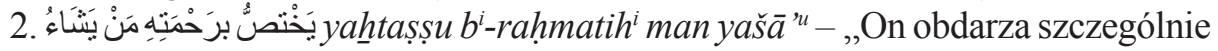
Swoim miłosierdziem tego, kogo chce" (S. II, 105; III, 74);

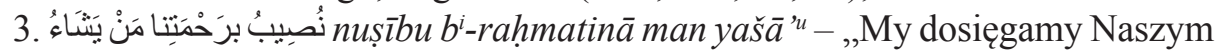
miłosierdziem tego, kogo chcemy" (S. XII, 56).

Wyrażają to również paralelizmy antytetyczne:

\begin{tabular}{|c|c|c|}
\hline \multicolumn{3}{|l|}{ S. XVII, 54} \\
\hline $\begin{array}{l}\text { „Jeśli On zechce, } \\
\text { okaże miłosierdzie, } \\
\text { albo jeśli zechce, } \\
\text { On was ukarze” }\end{array}$ & $\begin{array}{l}\text { 'in yaša' } \\
\text { yarhamkum } \\
\text { 'aw 'in yaša' } \\
\text { yu'add dibkum }\end{array}$ & 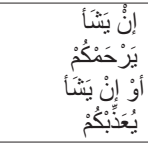 \\
\hline \multicolumn{3}{|l|}{ S. XXIX. 21} \\
\hline $\begin{array}{l}\text { "On karze tego, kogo chce, } \\
\text { i okazuje miłosierdzie, komu chce" }\end{array}$ & $\begin{array}{l}\text { yu 'adddubu man yašă'u } \\
\text { wa-yarhamu man yašă } u\end{array}$ & 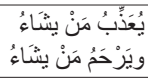 \\
\hline
\end{tabular}

Po spełnieniu określonych warunków wierni mogą uzyskać miłosierdzie. Nie należy się ono bowiem ludziom samo przez się (يَّ had o miłosierdziu poczytywany jest za rodzaj zuchwałości (S. XLI, 50). Przede wszystkim takim warunkiem uzyskania miłosierdzia jest słuchanie Boga i tego, co zostało przekazane przez proroka Muḥammada. Koniecznym warunkiem do zbawienia jest postępowanie według wskazań błogosławionego Koranu. Bogobojność jest w tym 
przypadku konieczną cnotą. Gdy Koran jest recytowany, należy przysłuchiwać się w milczeniu. Konieczną rzeczą jest odprawianie modlitwy i dawanie jałmużny. Łączy się to z prośbą o przebaczenie. Stawiane są też wymagania życia w pokoju między braćmi. Te zalecenia podsumowywane są formułą, która również wskazuje

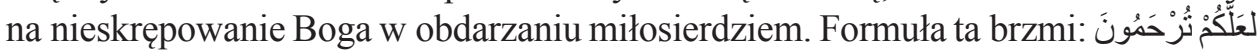
la allakum turhamūn ${ }^{a}$ - „Być może wy dostąpicie miłosierdzia” (S. III, 132; VI, 155; VII, 63. 204; XXIV, 56; XXVII, 46; XXXVI, 45; XLIX, 10). Inna jej wersja to: عَنَى رَبَكُْْم أَنْ يَرْحَحْكُْْ 'asà rabbakum 'an yarhamakum -,,Być może wasz Pan zmiłuje się nad wami” (S. XVII, 8). W innym przypadku jest mowa o pewności otrzymania miłosierdzia z podobnych powodów, jak wymienione poprzednio. Kończy się to tym

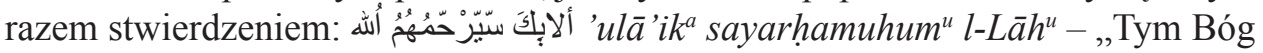
okaże miłosierdzie" (S. IX, 71; por. IX, 61). Dla zaznaczenia tej pewności użyty zostaje w tym miejscu czas przyszły.

Koran mówi wręcz, że niemożliwe jest jakiekolwiek zbawienie bez Bożego miłosierdzia. Żaden ludzki czyn nie zasługuje na zbawienie. Bez łaski Bożej i Bożego miłosierdzia ludzie poszliby za szatanem. Dla wyrażenia tego zostaje zastosowana

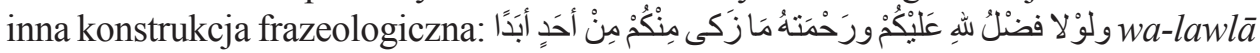
fad ll l-Lā $h^{i}$ 'alaykum wa-raḥmatuh ${ }^{u}$ mā zakà minkum min 'ahad ${ }^{i n}$ 'abad ${ }^{a n}$ - „A gdyby nie łaska Boga nad wami i nie Jego miłosierdzie, to nikt spośród was nie oczyściłby się nigdy!” (S. XXIV, 21; por. II, 64; IV, 83; XXIV, 10. 14. 20).

Bóg, który w całkowicie suwerenny sposób okazuje miłosierdzie, nie tylko jest miłosierny. On jest Miłosierdziem. Jego istotą jest Miłosierdzie. Tę szczególną tajemnicę wiary wyraża tekst Koranu następującym stwierdzeniem:

\begin{tabular}{ll}
\hline S. VI, 54 (por. VI, 12) & \\
\hline $\begin{array}{l}\text { "Wasz Pan przypisał samemu Sobie } \\
\text { miłosierdzie” }\end{array}$ & $\begin{array}{l}\text { kataba rabbukum 'alà nafsih } \\
\text { r-rahmat }\end{array}$ \\
\hline
\end{tabular}

Koran zaleca modlitwę do Bożego miłosierdzia:

\begin{tabular}{|c|c|c|}
\hline \multicolumn{3}{|l|}{ S. VII, 56} \\
\hline „Wzywajcie Go z obawą i nadzieją! & wa-d'ūh haw $h^{\prime a n}$ wa-tama ${ }^{\text {aan }}$ & و اذذعُوهُ خَوْفَا وطمتعًا \\
\hline Zaprawdę, miłosierdzie Boga jest bliskie & 'inn ${ }^{a}$ raḥmat $l-L \bar{a} h^{i}$ qarì $^{u n}$ & إنَّ رَخْمَة الِله قِرِيبُ \\
\hline dla ludzi czyniących dobro!” & $\min ^{a} l-m u h \sin \overline{i n}{ }^{a}$ & مِنَ المُحْسِنِينَ \\
\hline
\end{tabular}

\section{Modlitwa o miłosierdzie}

Jego miłosierdzie jest ponad wszystkim stworzeniem. Mówi o sobie, że: rahmatī wasi at kull ${ }^{a}$ šay ${ }^{\text {'in }}$ - ,Moje miłosierdzie obejmuje każdą rzecz" (S. VII, 156). Dlatego miłosierdzie Boże jest lepsze ( خَيِْ hay hay $\left.{ }^{u n}\right)$, niż wszystko, co człowiek posiada i wypracowuje swoim trudem codziennym (S. XLIII, 32). Z tego powodu w Koranie znajdują się dość liczne przykłady modlitw do miłosierdzia Bożego i prośby o miłosierdzie Boże. Ludzie poszukują bowiem 
największego zbliżenia do Boga, mając nadzieję na Jego miłosierdzie (S. XVII, 57).

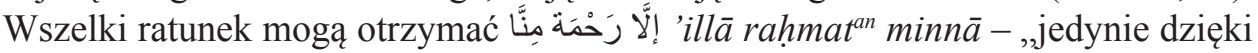
Naszemu miłosierdziu" (S. XXXVI, 44). Jest nie do pomyślenia, by ten, kto spełnia rytuał modlitwy, padając na twarz i wstając, i troszczy się o życie ostateczne, nie otrzymał Bożego miłosierdzia (S. XXXIX, 9; por. VII, 49). Słowa tych modlitw są skierowane do Boga przez patriarchów Starego Testamentu, proroków czy aniołów u tronu Bożego.

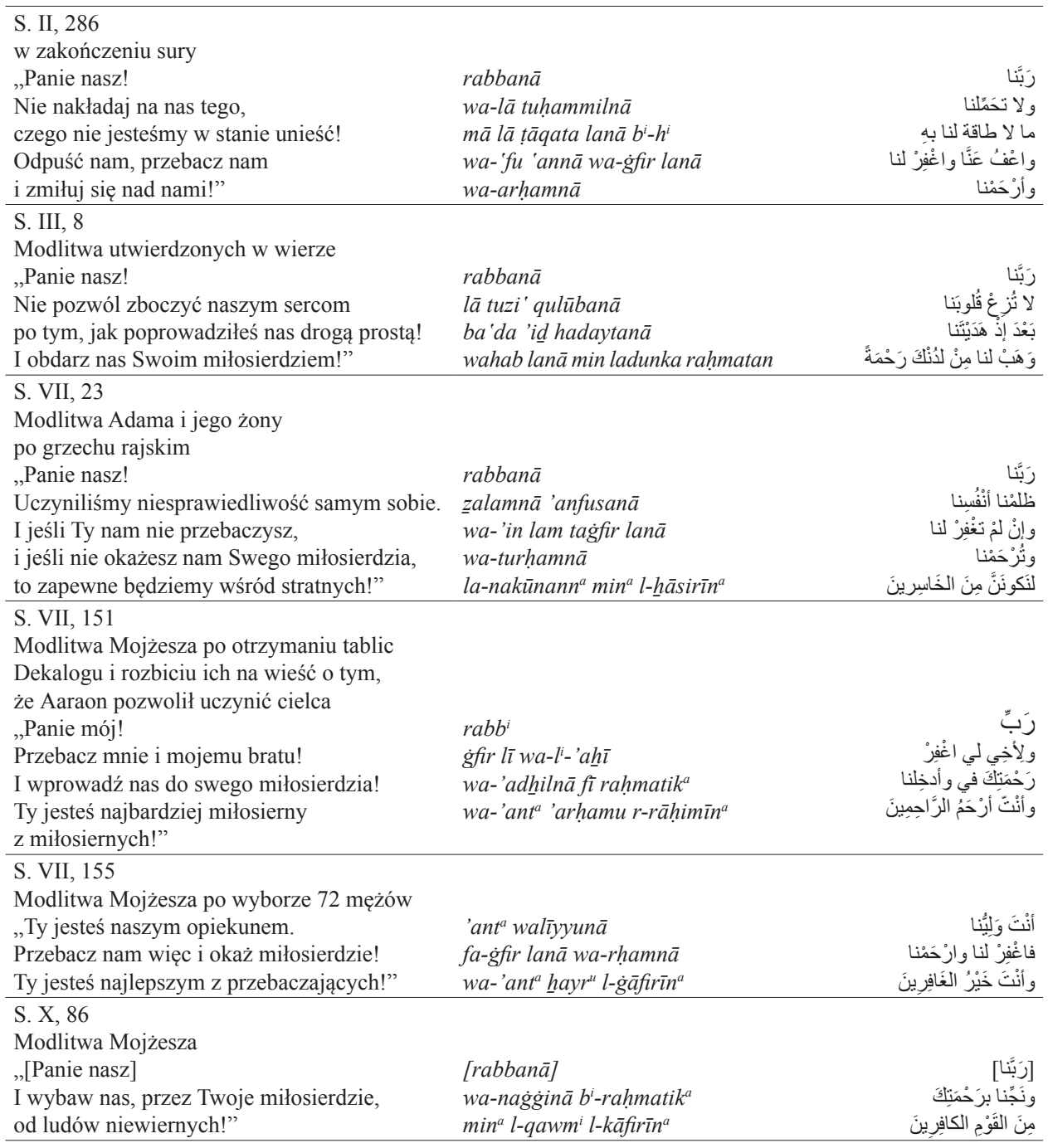




\section{S. XI, 47}

Modlitwa Noego

„Panie mój!

Uchowaj mnie od tego,

$r a b b^{i}$

abym Ciebie miał prosić o to, czego nie znam.

Jeśli Ty mi nie przebaczysz, i jeśli nie okażesz

mi miłosierdzia,

'inn̄̄ 'a' $\bar{u} d u b^{i}-k^{a}$

'an 'as'alak' mā laysa lì $b^{i}-h^{i}{ }^{\prime} i l m^{u n}$

wa-'illā taǵfir lì

wa-tarhamnī

to będę wśród tych, którzy ponoszą stratę"

'akun min $^{a}$ l-hāsirīn

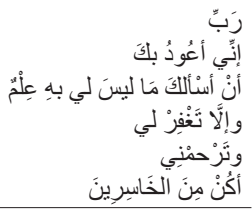

S. XXIII, 118

Modlitwa posłańca

„Panie mój!

Przebacz i zmiłuj się!

rabbi

gfir wa-rham

Ty jesteś najlepszy z miłosiernych!"

wa-'anta hayru r-rāhimìna

S. XXVII, 19

Modlitwa Salomona

„Panie mój!

Pobudź mnie, abym by wdzięczny

za Twoją dobroć, którą mnie napełniłeś

i moich rodziców;

$r a b b^{i}$

'awzi'n̄̄ 'an 'aškura

ni'mataka l-latī 'an 'amta

'alayy ${ }^{a}$ wa-'alà wālidayy ${ }^{a}$

i abym czynił dobro, które by się tobie podobało.

wa-'an 'a 'mala șālih ${ }^{a n}$ tard

Wprowadź mnie, przez Twe miłosierdzie

wa-'adhiln̄̄ bi-raḥmatik ${ }^{a}$

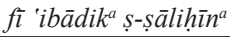

pomiedzy Twoje sługi sprawiedliwe!"

S. XL, 7.9

Modlitwa aniołów u tronu Bożego

„Panie nasz!

Ty obejmujesz każdą rzecz

miłosierdziem i wiedzą.

Przebacz tym, którzy się nawrócili,

i którzy poszli po Twojej drodze;

i ochroń ich od kary ognia piekielnego!

[...]

I uchroń ich od złych czynów!

A kogo Ty uchronisz od złych czynów,

już tego dnia

okazałeś mu swoje miłosierdzie.

A to jest osiągnięcie ogromne!"

rabbanā

wasi 'ta kulla šay 'in

rahmat ${ }^{a n} w a-$ 'ilm $^{a n}$

fa-g̈fir li-l-lad $\bar{d} n^{a} t a \bar{b} b \bar{u}$

wa-ttaba' $\bar{u}$ sabīlak ${ }^{a}$

waqihim 'ad̄āb l-ḥagīim ${ }^{i}$

[...]

waqihim $^{u} s$-sayy $\bar{\imath}^{\prime} \bar{a} t^{i}$

wa-man $\operatorname{taq}^{i} s$-sayy ${ }^{\prime}{ }^{\prime} t^{i}$

yawma 'id ${ }^{\text {in }}$

fa-qad rahmatah ${ }^{u}$

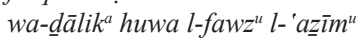

رَبَِّ

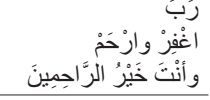

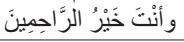

Owocem takich modlitw jest ratunek, jaki otrzymują na przykład Szu ajb,

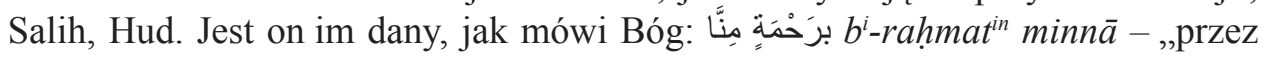
miłosierdzie od Nas" (S. VII, 72; XI, 58. 66. 94). O innych, takich jak Lot, Isma 'il, Idris, Zu-1-Kifla, mówi Bóg, że و ادْخُلْنَاهُهْ في رَحْمَنِنَ wa-dhulnāhum fi rahmatinā - „i wprowadziliśmy ich do Naszego miłosierdzia” (S. XXI, 75. 86). Środowisko, w رَحْمَة الله rahmat ${ }^{u}$ l-Lāh ${ }^{i}$ - „miłosierdziem Boga” (S. III, 107). Jest ono oddzielone murem od miejsca cierpienia potępionych:

\begin{tabular}{|c|c|c|}
\hline \multicolumn{3}{|l|}{ S. LVII, 13} \\
\hline „I zostanie wzniesiony mur między nimi, & fa-șuriba baynahum $b^{i}-s \bar{u} r^{i n}$ & فصُرب بَبَينهُهُ بْسُور \\
\hline który będzie miał bramę; & $l a h^{u} b \bar{a} b^{u n}$ & لهُلَبَابٌ \\
\hline wewnętrzna jego strona - miłosierdzie, & bātinuh fìh $^{i} r$-rahmmat ${ }^{u}$ & باطِنِّهُ فِيهِه الرََّحْمَة \\
\hline a zewnętrzna jego strona - kara" & wa-zāhiruh ${ }^{u}$ min qibalih $l^{i}{ }^{\prime} a \underline{d} \bar{a} b^{i}$ & 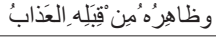 \\
\hline
\end{tabular}


Odwrócenie kary od człowieka w Dniu Ostatecznym oznacza, że فقدَ رَحِهَ fa-qad rahimah $^{u}$ - „że On zmiłował się nad nim” (S. VI, 16).

Również w życiu doczesnym Bóg obdarza człowieka swym miłosierdziem. Wyrazem tego jest stwierdzenie, że ożywienie przez Boga przyrody w cyklu rocznym

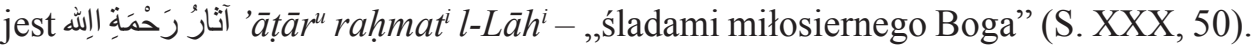
Różne znaki na niebie i na ziemi są zwiastunami Jego miłosierdzia:

\begin{tabular}{|c|c|c|}
\hline S. XXVII, 63 & & \\
\hline „On jest Tym, który prowadzi was drogą prostą & 'am-man yahdīkum & 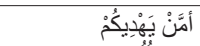 \\
\hline w ciemności & $f_{\imath} \underline{z} u l u m \bar{a} t^{i}$ & في ظلْمَةِة \\
\hline na lądzie stałym i na morzu, & l-barr ${ }^{i} w a-l-b a h r^{i}$ & \\
\hline i który posyła wiatry & wa-man yursilu r-riyāh ${ }^{a}$ & و ومَنْ يُرْسِلِ \\
\hline jako wieść zwiastującą Jego miłosierdzie. & bašr ${ }^{a n}$ bayn $^{a}$ yaday rahmatih ${ }^{i}$ & بَبْرُرًا بَيْنَ يَذَبْ رَحَحَتِهِ \\
\hline Czy istnieje jakiś inny Bóg obok Boga? & 'a-'ilā $h^{u n} m a^{\prime} a l-L \bar{a} h^{i}$ & 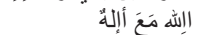 \\
\hline Bóg jest wyniosły ponad to, & ta'ālà $l-L a \bar{a} h^{u}$ & تِعَالى آآلَّهُ \\
\hline co Jemu przypisuja jako współtowarzyszy!" & 'ammā yušrikūn ${ }^{a}$ & عَمَّا بُشْرْرُوَنَ \\
\hline
\end{tabular}

\section{Miłosierdzie w Koranie a prawdy chrześcijańskie}

Znaki zwiastujące miłosierdzie Boże pochodzą od Boga. W wersie przytoczonym wyżej widać jednak polemikę z chrześcijańską tajemnicą Trójcy Świętej, która jest uznana przez twórcę islamu za zniekształcanie prawdziwej wiary. Bóg jest absolutnie jeden i nie jest On w Trzech Osobach. Podobny akcent polemiczny wiąże się z Osobą Jezusa. Jezus, syn Maryi, jako jeden z posłańców poprzedzających Muhammada, otrzymał od Boga Ewangelię. Została ona złożona w sercach ludzi w łagodności i miłosierdziu (رَأفة ورَحْمَة ra'afat ${ }^{a n}$ wa-rahmat ${ }^{a n}$ ). Jednakże Jego wyznawcy, czyli chrześcijanie, nie zachowali wiary tak, jak powinni byli ją zachować. Za odstępstwo

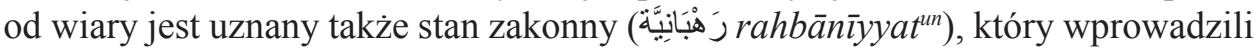
- według opinii wyznawców islamu - wbrew woli Boga. Dlatego nagrodę otrzymali ci spośród nich, którzy przyjęli prawdziwe - w opinii twórcy islamu - orędzie, którym jest jego nauka (S. LVIII, 27).

Idea Bożego miłosierdzia w Koranie nie wykazuje zbyt wielu stycznych z biblijną nauką o Bożym miłosierdziu. Po odrzuceniu przez autora Koranu całej chrystologii i soteriologii chrześcijańskiej pozostało już tylko miejsce na samodzielną refleksję nad tym zagadnieniem. W warstwie leksykalnej poskutkowało to dość ubogim słownictwem dla wyrażenia tej idei. Jest ono wzbogacane i uzupełniane słownictwem z innych zakresów, przede wszystkim z dziedziny pochodnej miłosierdziu, jaką jest przebaczenie. Ponadto autor tworzy pary desygnatów poszerzających semantykę wyrażeń utworzonych od omawianego rdzenia, by zrekompensować tym elementy zredukowane. 


\section{Rola wyrażeń opartych na rdzeniu رأف r'f}

Ideę zbawienia wyraża motyw dobrotliwości, dobroci Boga, która objawia się

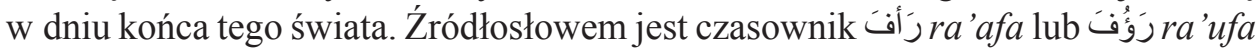

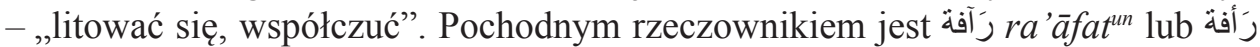
ra'fat ${ }^{u n}$ - „litość, współczucie” ${ }^{13}$.

Do Boga odnosi się przymiotnik رَوَُّ ra’ufü - ,dobry, dobrotliwy, litościwy, łaskawy". Ten przymiot wyraża relację Boga do wiernych, którzy Mu służą:

S. II, 207; III, 30

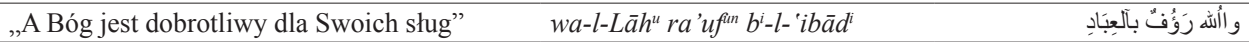

Ujawni się w Dniu Ostatecznym, kiedy przerażenie ogarnie wszystkie dusze, gdy zobaczą - jak w zwierciadle - swoje uczynki i dalszy ich los będzie zależeć tylko od Boga. Specjalna opieka Boża nad wyznawcami islamu okaże się właśnie w tym Dniu.

Idea ta jest w pewnym sensie uniwersalna. Jest tak przedstawiana wtedy, gdy mowa o specjalnym posłannictwie narodu arabskiego uznającego posłannictwo Proroka. Muzułmanie mają być świadkami dla wszystkich ludzi, tak jak Prorok jest świadkiem wobec nich. Na przyjęciu tego świadectwa opiera się zbawienie ludzi. Bóg nigdy nie zapomni o wierze tych, którzy przyjęli Jego wolę (S. II, 143). W tym przypadku wspomniana wyżej formuła przybiera bardziej uniwersalną postać:

$$
\text { S. II, } 143
$$

\begin{tabular}{|c|c|}
\hline $\begin{array}{l}\text { „Zaprawdę, Bóg jest dla ludzi } \\
\text { dobrotliwy, litościwy!” }\end{array}$ & $\begin{array}{l}\text { 'inna l-Lāa } h^{a} b^{i}-n-n \bar{a} s^{i} \\
\text { la-ra'uffin } \text { rahịm }^{u n}\end{array}$ \\
\hline
\end{tabular}

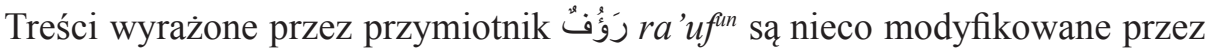

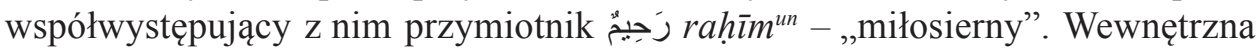
dobroć Boga (świętość) uzewnętrznia się bowiem w postaci miłosierdzia nad grzesznymi ludźmi ${ }^{14}$.

To określenie ma swoje korzenie w Starym Testamencie. Dokładnie odpowiada

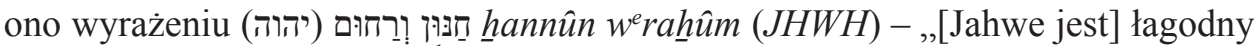

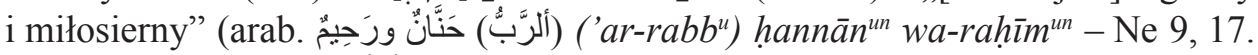

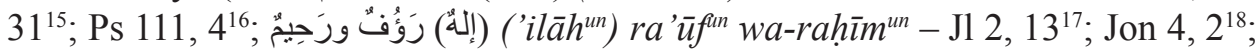
por. Jr $\left.21,7^{19}\right)$. Drugie podobne biblijne wyrażenie jest inwersją powyższego:

${ }^{13}$ Por. A. A. Ambros, S. Procházka, A Concise Dictionary..., s. 106; R. Baalbaki, AL-MAWRID. A Modern Arabic-English Dictionary, s. 571; Х. К. Баранов, Арабско-русский словарь, s. 280; J. Danecki, J. Kozłowska, Słownik arabsko-polski..., s. 357; F. Dieterici, Arabisch-deutsches Handwörterbuch.., s. 59; J. Łacina, Stownik arabsko-polski, s. 435; A. A. Nadwi, Vocabulary..., s. 206; 'A. M. 'Omar, Dictionary..., s. 195; J. Penrice A Dictionary..., s. 54; H. Wehr, Arabisches Wörterbuch ..., s. 286.

${ }^{14}$ Por. J. Nosowski, Teologia Koranu..., s. 77-78.

${ }^{15}$ Por. BH, s. 1447, 1449; ABST, s. 650.

${ }^{16}$ Por. BH, s. 1194; ABST, s. 779.

${ }^{17}$ Por. BH, s. 1011; ABST, s. 1113.

${ }^{18}$ Por. BH, s. 1033; ABST, s. 1129.

${ }^{19}$ Por. BH, s. 823; ABST, s. 950. 
אֵֵ רַחוּם וְחַּוּן

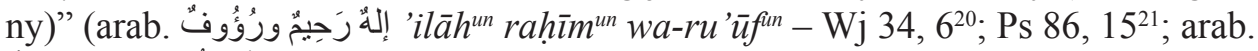

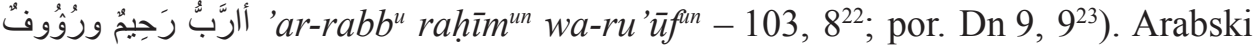

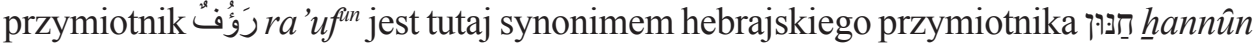
w znaczeniu „miłosierny, łaskawy”24. W przekładach na język arabski pojawia się inny jego synonim, nie występujący w Koranie, a mianowicie rzeczownik حَنَّنُ hannān $n^{u n}$ - „miłość, współczucie, sympatia, czułość” ${ }^{25}$.

Wyrażenie oparte na omawianym rdzeniu występuje także w kontekście polemiki $\mathrm{z}$ tradycją chrześcijańską. Chodzi mianowicie o pośrednie uznanie zbawczego posłannictwa Jezusa, syna Maryi. Przyszedł On bowiem jako posłaniec Boży z Ewangelią, Ci, którzy poszli za Jego nauką, czyli chrześcijanie, otrzymali w swoich sercach

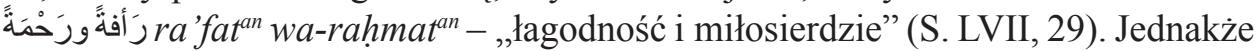
chrześcijanie wszystko popsuli i nie zachowali depozytu powierzonego im przez Boga takim, jaki był im przekazany. Przykładem jest życie zakonne, które w opinii Koranu nie pochodzi od Boga. Niektórzy tylko zostali zbawieni, a pozostali stali się bezbożnymi. Polemika z doktryną chrześcijańską dotyczy więc w tym wypadku daru Bożego o charakterze zbawczym, co jednak u chrześcijan nie zostało zachowane zgodnie z zamysłem Boga.

Wydaje się uzasadniona opinia, że wyrażenia oparte na omawianym rdzeniu są w Koranie komplementarne w odniesieniu do omawianych wyżej wyrażeń opartych na rdzeniu رحمh.

\section{Summary}

\section{Divine mercy as synonime of salvation in Quran. Linguistic and theological reflection}

There is the idea of divine mercy in Quran. It is expressed by the words of Arabic vocabulary derivated from the triliteral verbal root $ر ح \mathrm{rhm}$. The fundamental means of expressing the mystery

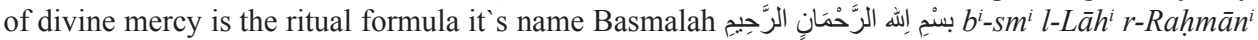

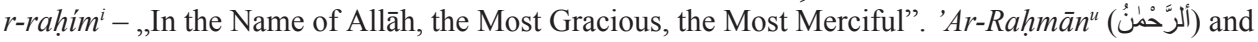

${ }^{20}$ Por. BH, s. 144; ABST, s. 121.

${ }^{21}$ Por. BH, s. 1168; ABST, s. 762.

${ }^{22}$ Por. BH, s. 1182; ABST, s. 771.

${ }^{23}$ Por. BH, s. 1403; ABST, s. 1093.

${ }^{24}$ Pochodzi on od czasownika חָָ hִānan - ,być przychylnym, łaskawym, dobrym; litować się”. Por. P. Briks, Podręczny stownik hebrajsko-polski i aramejsko-polski Starego Testamentu, Warszawa 1999, s. 121; L. Koehler, W. Baumgartner, J. J. Stamm, Wielki słownik hebrajsko-polski i aramejsko-polski Starego Testamentu, tłum. red. P. Dec, Warszawa 2008, t. 1, s. 316; Ф. Л. Шапиро, Б. М. Гранде, Иврит-русский словарь, Москва 1963, s. 211.

${ }^{25}$ Pochodzi on od czasownika نَ hanna - ,współczuć, litować się, obdarowywać uczuciem”. Por. R. Baalbaki, AL-MAWRID. A Modern Arabic-English Dictionary, s. 492; Х. К. Баранов, Арабскорусский словарь., s. 197-198; J. Danecki, J. Kozłowska, Stownik arabsko-polski..., s. 304; J. Łacina, Stownik arabsko-polski, s. 325, 327, 798; H. Wehr, Arabisches Wörterbuch..., s. 189. 


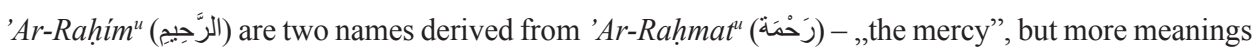
that pertain to mercy than 'Ar-Rahim . This formula means the belonging to a community of Islam

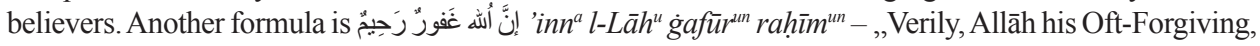
Most Merciful!” (S. V, 34. 39; IX, 9. 99. 102; XLIX, 14; LXXIII, 28) and its modifications. It's used to confirm the credibility of the truths of faith and the moral norms divinely revealed. The divine revelation in Quran and its realisation in earthly life is signified with the followings pairs of derivatives

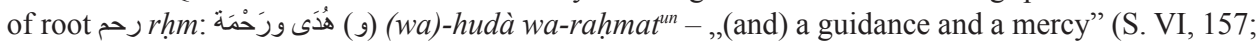

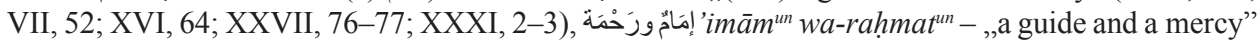

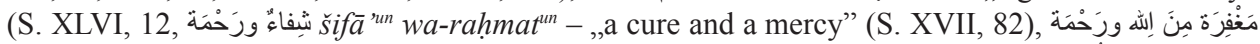

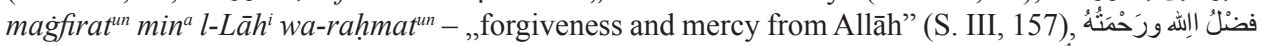

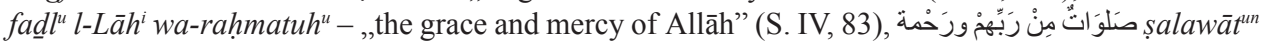
min rabbihim wa-rahmat ${ }^{u n}$, ,who are blessed from their Lord and receive His mercy" (S. II, 157). Allāh, the Most Merciful, is absolutely independent in giving salvation. It is signified with phrase

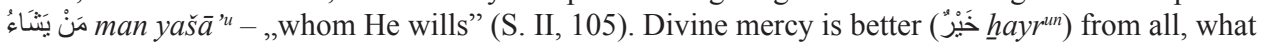
man has on earth. Therefore in Quran there are more prayers for divine mercy and to divine mercy. Complementary to words derivated from the root رحم rhm are the derivatives from the root ر ر r'f. In spite of more similiarity to biblical science about divine mercy, the author of Quran created own divine mercy conception. He throws away all of trinitology, christology, soteriology and staurology.

\section{Keywords}

Allah, Divine mercy, Islam, Quran, salvation 
